\title{
Factors that Influence Teachers' Pedagogical Use of ICT in Secondary Schools: A Case of Ghana
}

\author{
Charles Buabeng-Andoh \\ University of Education, Ghana \\ ORCID: 0000-0003-3781-684X
}

\begin{abstract}
Technology is perceived as a vital driving force for contemporary education. The Government of Ghana acknowledges the relevance of Information and Communication Technology (ICT) in education, and it is financing ICT in secondary schools. However, most instructors are unwilling to integrate ICT into their teaching. Therefore, the purpose of this study was to investigate the factors that influence secondary school teachers' ICT usage in schools. The participants were 376 teachers randomly selected from 24 public and private schools. The data collected from the participants were analyzed by using descriptive statistics and analysis of variance. The results showed that teachers' use of ICT was still confined to basic and traditional activities such as search for information, class presentation etc. Internal and external factors were found to influence teachers' ICT usage. Also, female teachers reported that they use ICT more than male teachers. In general, this study has contributed to the literature regarding teachers' pedagogical use of ICT in secondary schools and also their gender differences in the use of ICT.
\end{abstract}

Keywords: Public and private schools; Pedagogical use; Expectancy-value model; Secondary school teachers; External factors; Internal factors

\section{Introduction}

ICT is becoming increasingly important in our daily lives and in our educational system. For example, the usage of ICT has challenged conventional teaching methods, transformed instructional practices and contributed to emerging new instructional methods (Tezci, 2011). With its prospects, ICT usage has become an important component of educational reform and an integral part of the school curriculum (Papanastasiou \& Angeli, 2008). The educational prospects of ICT usage include enriched learning environments, permitting learners to embrace several perspectives on complex phenomenon, encouraging flexible knowledge construction in complex learning domains and catering for individual differences (Sang et al., 2010).

However, research studies have shown that many teachers are unwilling to integrate ICT into their teaching (Haugsbakk, 2010; Tezci, 2011). Studies have highlighted a number of factors to explain why teachers are reluctant to use ICT in their schools. These include, lack of ICT skills, inadequate computer access and inadequate time (Albirini, 2004; Chen, 2010; Japhet \& Usman, 2018). 
Despite, numerous efforts by writers to study the factors that affect teachers' ICT integration, research studies have found that teachers' pedagogical use of ICT have fallen below acceptable standards and the factors that contribute to their integration have received little attention by researchers (Albirini, 2004; Sipila, 2014). Though, several researchers conducted studies on teachers' pedagogical use of ICT, they employed few number of factors and participants in their studies (Aslan \& Zhu, 2017; Kamau, Kimani, \& Muthoni, 2016), the current study used a large number of factors and participants based on gender, school programs and school location to explore teachers' pedagogical use of ICT (i.e. teachers' ICT usage in teaching). It is obvious that investigating a new study which include a huge number of instructors from different departments is essential to identify perceived value, expectancy of success, self-efficacy, competence, training, access to computers, support from leaders and means of applying technology. Hence, this study is conducted to deal with this missing element. The findings of this study would help policymakers, researchers, and teachers to understand the position of Ghana with regards to the use of ICT in secondary schools. Teachers play key roles in the integration of ICT. They are anticipated to use technology in their teaching. Therefore, it is crucial to understand their pedagogical use of ICT in teaching and the factors that influence their ICT use in their teaching. This study used both internal factors (perceived value, expectancy of success, self-efficacy and competence) as well as external factors (training, computer accessibility and leadership support) to examine those factors that influence teachers' pedagogical use of ICT in schools. Literature on these factors are given below.

\section{ICT Integration}

The integration of ICT into teaching and learning is seen as a priority by many governments and educational institutions worldwide. Many governments have developed a number of Master Plans dealing with ICT in education (Pelgrum \& Anderson, 1999) as well as spent millions of dollars on educational infrastructure and professional development teachers and other categories of staff. However, despite all these investments, evidence suggests that ICT has not been greatly integrated into teaching and learning activities (Grabe \& Grabe, 2008; Player-Koro, 2012). Previous studies found that teachers' knowledge and skills in technology influence their use of technology in teaching and learning process (Aydin, 2013; Japhet \& Usman, 2018;). For example, studies found that teachers frequently use ICT for informative, organizational, recreational, lesson planning purposes (Brun \& Hinostroza, 2014; Ola, Anders, \& Göran 2017; Shin, 2015; Wikan \& Molster, 2011) and infrequently use ICT for simulation programs and software (Aslan \& Zhu, 2017; Aydin, 2013). Therefore, ICT integration into teaching is limited to few specific resources and frequently applied to perform traditional teaching activities (Brun \& Hinostroza, 2014). While ICT has been used in various ways to support teachers, some of the literature points to the fact that little evidence exists supporting the claim that ICT has transformed education (Twining \& Henry, 2014). Therefore, researchers have indicated that it is imperative to study the way ICT is used in schools and to identify the factors that contribute to teachers' use of ICT (Chen, 2010; Wong, Teo \& Russo, 2012).

Research studies that investigated gender role on ICT usage reported mixed findings. Though, some scholars (Majuto \& Gibert, 2015; Mustafa, 2014) found gender differences in the use of ICT in teaching, other scholars (Aslan \& Zhu, 2017; Fomsi \& Orduah, 2017) did not find any significant differences in genders' use of ICT in teaching. 


\section{Perceived Value and Expectancy of Success}

Feather (1982), Wigfield (1994), and Wigfield and Eccles (2000) proposed an expectancy-value model of motivation. The theory is used for understanding and predicting people's behavior in the process of adopting innovations. Expectancy-value theory suggests that person's decision to do a particular task depends on the belief that there are advantages in executing the task and belief that they can succeed. In other words, the expectancy of success and perceived value must be high. Wozney, Venkatesh, and Abrami (2006) adopted expectancy-value theory to study teachers' ICT implementation in school. They found that teachers' perceived value and expectancy of success were the most significant predictors of their ICT use. Teachers who believed that ICT can immensely improve teaching and learning seemed to be technologically innovative. Furthermore, researchers (Khawaji, 2016; Kwon \& Chang, 2009) found that perceived value, expectancy of success and perceived cost of using ICT than perceived cost significantly relate to teachers' integration of technology. Finally, a study by Appianing and Van Eck (2015) found that males reported higher perceived value and higher expectancy of success of technology than their female counterparts.

\section{ICT Competence}

ICT competence is defined as being able to handle a wide range of varying ICT applications for various purposes (Ilomaki, Kantosalo, \& Lakkala, 2011). Several studies revealed that teachers' ICT competence together with their attitudes determine both their initial use of ICT and future behavior towards technology (Chun-Mei, Chien-Hua, His-Chi, \& Tsu-Chuan, 2018; Japhet \& Usman, 2018). Sipila (2014) investigated teachers' perceptions of ICT integration, the level of their ICT competence and the factors that might hinder their use of ICT in schools. The study concluded that teachers who are competent in the use of ICT often integrate the technology into their lessons. In a similar study, Cakir and Yildirim (2013) investigated ICT teachers' professional growth viewed in terms of perceptions about teaching and competencies. The result found that teachers' perceptions and competencies are the important factors for their professional growth. Also, researchers (Aslan \& Zhu, 2017) found that ICT confidence and ICT competence related to teachers' integration of ICT into their teaching. Finally, Pelgrum (2001) found that successful implementation of ICT in schools depends mostly on teachers' competencies levels. However, Drent and Meelissen (2008) found that the impact of ICT competence on the innovative use of ICT is small. They indicated that innovative educators develop their competence based on the teaching goals they want to accomplish with ICT. The use of ICT in schools remains a critical concern for both teachers and students to perform effectively. Therefore, teachers are required to be competent in the use of ICT (Voogt \& Roblin, 2012; Pineida, 2011). Research studies on gender differences in ICT competency has reported mixed results. Some scholars (van Deursen \& van Dijk, 2015; Kaarakainen, Kivinen, \& Vainio, 2017) reported significant gender differences in ICT competency, but other scholars (Ritzhaupt, Liu, Dawson, \& Barron, 2013) reported no significant differences in ICT competency.

\section{Computer Self-efficacy}

Self-efficacy is defined as a belief in one's own abilities to perform an action or activity necessary to achieve a goal or task (Wong, Teo, \& Russo 2012). Self-efficacy can be considered as the confidence that an individual has in one's ability to do things that one strives to do. Prior studies 
(Brun \& Hinostroza, 2014; Liaw, Huang, \& Chen, 2007; Player-Koro, 2012; Yuen \& Ma, 2008) found that teachers' self-efficacy or confidence relate to their use of ICT in teaching. Moreover, in a study conducted in Turkey, Tezci (2011) found that teachers' self-confidence levels in the use of ICT were moderate. He posited that teachers' confidence levels with regard to ICT integration in education should be high in order for them to be motivated to use ICT, which in turn would result in successful implementation of ICT in classrooms. Finally, Hassan, Rosnaini, and Su (2016) conducted a study on teachers' acceptance and integration of ICT in classroom. A total of four teachers were interviewed. The results showed that teachers' confidence relates to their ICT usage. The researchers concluded that when a teacher is self-confident, he or she would possess positive attitudes toward ICT, and would be interested to integrate ICT into teaching. However, in another study, Wikan and Molster (2011) reported that teachers were not confident in using ICT in their teaching despite taking courses in ICT. Studies that explored gender role on ICT self-efficacy reported mixed findings. Tarhini, Hone, and Liu (2014) found no significant gender differences in ICT self-efficacy but Bao, Xiong, Hu and Kibello (2013) found significant gender differences in technology self-efficacy.

\section{Training}

Teachers' training is a key factor to successful integration of computers into classroom teaching. Several studies have revealed that whether beginner or experienced, ICT-related training programs develop teachers' competencies in computer use (Aydin, Gurol, \& Vanderlinde, 2016; Vitanova, Pachemska, \& Pachemska, 2014; Wozney et al., 2006) and influence teachers' attitudes towards computers (Hew \& Brush, 2007). In a similar study, Chen (2010) found that training is the strongest determinant of teachers' technology use in schools. Furthermore, teachers support the claim that if they involve themselves in quality technology professional training which will improve their ICT competence, it is likely they will apply ICT in their teaching activities (Hutchson, 2012).

A common criticism of professional development activities designed for teachers is that they are too short and offer limited follow-up to teachers once they begin to teach. Lawless and Pellegrino (2007) claim that if training program is of high quality, the period for training lasts longer, new technologies for teaching and learning are offered, educators are eagerly involved in important context activities, teamwork among colleagues is improved and has clear vision for students' attainment. Wikan and Molster (2011) reported that teachers who had had short-term ICT training, lack confidence and competence in using ICT and also do not know how to use ICT to improve and support students' learning. Training programs for teachers that embrace educational practices and strategies to address beliefs, skills and knowledge improve teachers' awareness and insights in advance, in relation to transformations in classroom activities (Levin \& Wadmany, 2008). Furthermore, Mulhim (2013) found that teachers' low level of ICT usage is due to lack of training. The result suggested an urgent need to train teachers in pedagogical and technical use of ICT in schools.

The literature revealed that ICT training programs develop teachers' competencies in computer use. It is also evident from the literature that other technological skills acquire by teachers are necessary but ICT training skills are important conditions for ICT integration into teaching process. Computer training will be used as a variable in this study since a review of the literature found that training is an important factor to determine teachers' technology use. 


\section{Computer Accessibility}

Access to ICT infrastructure and resources in schools is a necessary condition to the integration of ICT in education (Japhet \& Usman, 2018). Effective adoption and integration of ICT into teaching in schools depends mainly on the availability and accessibility of ICT resources such as hardware, software, etc. Therefore, access to computers, updated software and hardware are key elements to successful adoption and integration of technology. Obviously, if teachers cannot access ICT resources, then they will not use them. Therefore, hardware, software and network infrastructure must be accessible to teachers in schools. A study conducted by Wastiau and Pagano (2013) on the 'teacher effect' on the use of ICT in the classroom found that a smaller proportion of teachers work in conditions of high access to ICT in classroom. A similar study conducted by the European Commission (2013) found that the greatest obstacle to teachers' use of ICT in teaching is access to ICT. Access to technology resources does not imply only availability but also the suitability of tools and program to support teaching and learning (Tondeur, Valcke, \& van Braak, 2008b). Teachers who have access to the necessary technological resources are likely to integrate ICT into their teaching activities (Japhet \& Usman, 2018). However, many studies have found that the provision of ICT resources in schools does not guarantee its automatic use by teachers (Gulbahar, 2008b; Ertmer, 2005).

\section{Leadership Support}

It is easy to recognize that factors such as access to computers, network and internet access, provision of training to educators, provision of ICT-based curriculum resources and technical support are important for implementation of ICT in education. Many national policies on ICT in education make plans for provisions in these areas. However, these factors alone, would not be enough to bring about the sort of institutional change that would be necessary. Leadership engages the acquisition and coordination of these factors within the settings and limitations of the institution in defining and realizing the preferred results. Numerous studies (Boulton, 2017; Japhet \& Usman, 2018; Shin, 2015) have found that leadership support is a stronger determinant of teachers' integration of ICT into teaching. Schiller (2003) believes that "without the leadership support, the educational potential of information and communication technology may not be realized" (p. 171). Yet he claims that research literature has paid no attention to the significant role of principals in this aspect. Principals need to assume a major responsibility for initiating and implementing school change through the use of information and communications technology (p. 171). Also, Uluyol and Sahin (2016) confirmed that leadership support has been ignored irrespective of huge investment of technology in schools. They recommended that school administrators must show their total commitment to teachers' integration of ICT so that the value of the technology can be realized. Tubin (2007) conducted a study on the use of ICT in nine schools in Israel which successfully implemented ICT in teaching. He found that the leadership style can help ease the introduction of ICT into schools. Yet the task of providing effective leadership is a challenging one. For the use of ICT in teaching to be sustainable, leadership support and school community support are important. It is not the duty of a teacher (Wikan \& Molster, 2011).

\section{Context of the Study}

This study was conducted in Ghana, located in West Africa. The current education system in Ghana consists of six years of primary education, three years of Junior Secondary School (JHS), 
three years of Senior Secondary School (SHS) and four years of university degree programs. The first nine years of basic education are free and compulsory. Over 300,000 Ghanaian students sit for the Basic Education Certificate Examination (BECE) at the end of the third year of JHS (Form 3 or ninth grade) in seven subjects. Successful candidates go to public or private SHSs and Technical vocational institutes (TVI). At the end of SHS (twelfth grade), all students sit for the West African Senior Secondary Certificate Examination (WASSCE) in each of their seven or eight subjects. The state examinations influence the teaching and learning process since teachers in SHSs only teach to complete the syllabi before students take their external examination. This teacher-centered mode of teaching affect students' academic performance since they tend to rely on rote learning.

As part of Ghana government's efforts to transform the SHS curriculum, a national ICT policy known as Information and Communication Technology for Accelerated Development (ICT4AD) (Ministry of Education, 2003) was formulated and implemented in 2004. One key area the policy focused on was to promote ICTs in education by the deployment and exploitation of ICTs in education. To meet the challenges of education in the 21st Century, a new ICT in education policy was introduced in 2008 (Ministry of Education, 2008). The objective of this policy is to introduce ICT in SHSs through the teaching of ICT as a core and elective subject, the integration of ICT as a teaching tool for all subject areas and the integration of ICT to support educational management and administrative functions. Despite, the enactment of the ICT policies and the provision of ICT infrastructure, it has been revealed that teachers' integration of ICT into their teaching activity is still low in Ghana (Ministry of Education, 2008). Therefore, the purpose of this study was to identify the factors that influence teachers' ICT integration into their teaching practices.

\section{Research Questions}

Based on the literature, the study was guided by the following questions:

(1) What are teachers' pedagogical uses of ICT in schools?

(2) What are the views of teachers on factors affecting their ICT usage?

(3) Do teachers differ in their responses to the scale items by gender, school program and school location?

(4) What is the relative contribution of these factors to teachers' pedagogical use of ICT in learning?

\section{Methodology}

\section{Population and Sample}

In this study, 24 public and private secondary schools were randomly selected from a list of all public and private secondary schools in Ghana. The schools with the lowest student-computer ratio (Ministry of Education, 2008) were selected from four regions namely Greater-Accra, Central, Eastern, and Ashanti. The schools comprised three public secondary schools and three private secondary schools in each region. The categorization of the schools was urban schools, semi-urban schools, and rural schools. The participants were randomly selected using "table of random number" method. This method involved giving each participant in the population a 
serial number of identification and then selecting 850 arbitrary numbers from the population. Questionnaires were then distributed to the 850 participants. A total of 650 questionnaires were received, representing $77 \%$ return rate of 850 questionnaires distributed to teachers. Of these, 85 questionnaires were deemed unusable, due to data incompleteness, and were subsequently dropped from the data set leaving 575 questionnaires for data screening. Of these, 199 questionnaires were detected as outliers (i.e. cases with extreme values that distort statistics) and deleted from the data set leaving 376 for the data analysis.

\section{Instrument}

The questionnaire consisted of 47 items and was categorized into sections A, B, and C. Section ' $A$ ' consisted of seven demographic items. Section 'B' comprised ICT usage construct which contained five item statements on a five-point scale ranging from 1 (never) to 5 (daily). Section ' $C$ ' contained six constructs of ICT factors with 33 item statements. These constructs included (1) The computer competence construct adapted from (Albirini, 2004) which contained six item statements on a five-point scale ranging from 1 (no competence) to 5 (very high competence), (2) the access construct adapted from (Albirini, 2004) which comprised three item statement, (3) the leadership construct which contained four item statements, (4) the self-efficacy construct which comprised five item statements, (5) the perceived value construct which comprised six item statements, (6) the expectancy of success construct which comprised four item statements. The access, leadership, perceived value and expectancy of success constructs were all on a fivepoint scale ranging from 1 (strongly disagree) to 5 (strongly agree). A reliability test was carried out to determine the internal consistency of the items. The Cronbach alpha reliabilities $(\alpha)$ of the scales for the constructs ICT usage scale, competence scale, leadership scale, perceived value and self-efficacy were $0.94,0.92,0.85,0.73$, and 0.82 , respectively. The above reliabilities are in with in line with Kline's (2005) results. Also, the reliabilities of expectancy of success scale $(\alpha=0.57)$ and access scale $(\alpha=0.55)$ were in agreement with Caplan, Naidu, and Tripathi (1984) results.

\section{Data Analysis}

Descriptive statistics were used to analyze demographics of the participants, research questions 1 and 2. An ANOVA was conducted to analyze the differences in teachers' responses based on school programs and locations (Research question 3). Pearson correlation analysis was performed to determine the correlations among variables. Finally, multiple regression analysis was conducted to determine the relative importance of factors that relate to ICT integration (research question 4).

\section{Research Findings}

Of 376 respondents, $64 \%$ were males and $36 \%$ were females. The age of the teachers ranged from 20 to $50+$. Most of the teachers (63\%) were between 20 and 39 years of age. Only $14 \%$ were $50+$ years old. $64 \%$ of the teachers taught in public schools while $36 \%$ taught in private schools. $36 \%$ of the teachers taught in urban schools, $31 \%$ taught in semi-urban schools and $34 \%$ taught in rural schools. In terms of program, 26\% taught mathematics, 20\% taught science, $20 \%$ taught English and 33\% taught other programs (i.e. Business, Visual arts, General arts and Agric). 
Regarding ICT experience, $4 \%$ had less than 1year experience, 12\% had between 2 and 3 years' experience, $25 \%$ had between 4 and 5 years' experience and $59 \%$ had more than 5 years' experience. Finally, 30\% had between 1 and 5 years teaching experience while $26 \%$ had 16 and above teaching experience.

\section{Research Question 1: Teachers' ICT Usage in Teaching}

As seen in Table 1, majority of the teachers used ICT to search for learning materials from the internet (mean $=2.74$, standard deviation $=1.40$ ). However, teachers' use of ICT to support their teaching varies as follows: $34 \%$ never use ICT, whereas $15 \%$ use ICT daily. The overall pedagogical use of ICT was found to be low ( mean $=2.66$, standard deviation $=1.46$ ).

Table 1. Teachers' ICT Usage

\begin{tabular}{|c|c|c|c|c|c|c|c|}
\hline \multirow[t]{2}{*}{ Variable } & \multicolumn{5}{|c|}{ Percentage (\%) } & \multirow[t]{2}{*}{ Mean } & \multirow[t]{2}{*}{ SD } \\
\hline & Never & $\begin{array}{l}\text { Once a } \\
\text { month }\end{array}$ & $\begin{array}{l}\text { Once a } \\
\text { week }\end{array}$ & $\begin{array}{c}\text { Twice a } \\
\text { week }\end{array}$ & Daily & & \\
\hline $\begin{array}{l}\text { In-class search for } \\
\text { learning materials from } \\
\text { the internet }\end{array}$ & 26.3 & 19.9 & 19.9 & 18.1 & 14.4 & 2.74 & 1.40 \\
\hline Give class presentation & 41.5 & 14.9 & 17.8 & 13.0 & 11.4 & 2.37 & 1.43 \\
\hline Complete Assignment & 29.5 & 19.7 & 18.1 & 14.4 & 14.9 & 2.64 & 1.44 \\
\hline $\begin{array}{l}\text { Browse relevant } \\
\text { website }\end{array}$ & 32.2 & 18.4 & 15.4 & 13.3 & 8.1 & 2.66 & 1.51 \\
\hline $\begin{array}{l}\text { Process and analyze } \\
\text { data }\end{array}$ & 40.7 & 13.6 & 12.8 & 16.0 & 16.2 & 2.53 & 1.54 \\
\hline Overall ICT usage & 34.0 & 17.3 & 16.8 & 15.0 & 15.0 & 2.66 & 1.46 \\
\hline
\end{tabular}

\section{Research Question 2: Teachers' Perceptions on Factors Influencing Their ICT Usage}

The analysis of descriptive statistics found that the teachers' overall perception of perceived value of ICT was high ( $M=4.26, S D=.61$ ) as seen in Table 2 . This was followed by expectancy of success $(M=4.17, S D=.75)$. However, the teachers' overall level of training was perceived to be low $(M=2.63, S D=1.54)$.

Table 2. Overall Means and Standard Deviations of Factors

\begin{tabular}{lcc}
\hline Variable & $\mathrm{M}$ & $\mathrm{SD}$ \\
\hline Competence & 3.39 & 1.18 \\
Access & 3.45 & 1.38 \\
Leadership support & 3.39 & 1.16 \\
Self-efficacy & 4.11 & .83 \\
Training & 2.63 & 1.54 \\
Perceived value & 4.26 & .61 \\
Expectancy of Success & 4.17 & .75 \\
\hline
\end{tabular}

$\mathrm{M}=$ Overall mean, $\mathrm{SD}=$ Overall standard deviation 


\section{Research Question 3: Differences in Teachers' Responses to Scale Items Based on Gender, Programs and Locations}

A one-way between-subjects ANOVA compared the teachers' mean scores based on gender (see Table 3). All ANOVA assumptions were met. There was a statistically significant difference at the $p<.05$ level in mean scores for the scale items ICT usage $[F(1,372)=4.950, p=.010]$, leadership support $[F(1,372)=6.563, p=.011]$ and self-efficacy $[F(1,372)=9.164, p=.003]$. Surprisingly, females overall scores for ICT usage and leadership support scales were higher than those of the males. However, males overall scores for self-efficacy scale were higher than those of females.

Table 3. One-way ANOVA Results for Differences based on Gender

\begin{tabular}{clllccccc}
\hline Scales & Gender & $\mathrm{N}$ & $\mathrm{M}$ & $\mathrm{SD}$ & $\begin{array}{c}\text { Mean } \\
\text { Square }\end{array}$ & $\begin{array}{c}\mathrm{F} \\
(1,372)\end{array}$ & $p$ & $\eta^{2}$ \\
\hline ICT-U & Male & 240 & 2.46 & 1.27 & 11.236 & 4.950 & $.010^{*}$ & .020 \\
& Female & 131 & 2.82 & 1.33 & & & & \\
LS & Male & 241 & 3.29 & .98 & 6.115 & 6.563 & $.011^{*}$ & .020 \\
& Female & 133 & 3.56 & .93 & & & & \\
SE & Male & 241 & 4.12 & .67 & 4.113 & 9.164 & $.003^{*}$ & .024 \\
& Female & 133 & 3.90 & .66 & & & & \\
\hline
\end{tabular}

Note: $\mathrm{N}$ is population, ${ }^{*} p<.05$, ICT-U is ICT usage, LS is Leadership support, SE is Self-efficacy

Again one-way between-subjects ANOVA compared the teachers' mean scores based on the programs of the school (see Table 4). There was a statistically significant difference at the $p<.05$ level in mean scores for the scale items: leadership support $[F(3,372)=3.763, p=.011]$ and perceived value $[F(3,372)=3.902, p=.009]$. However, the effect size was small $(\eta 2=.009)$. Posthoc comparisons using Tukey HSD test indicated that English teachers $(M=3.58, S D=.93$ ) did not differ significantly from either Mathematics teachers or science teachers with regards to leadership. Also, post-host test revealed that the mean score for the science teachers ( $M=4.36$, $S D=.39)$ was significantly different from English teachers $(M=4.15, S D=.42)$ with regards to perceived value. The Mathematics teachers did not differ significantly from either English teachers or science teachers.

Table 4. One-way ANOVA Results for Differences Based on Programs of Study

\begin{tabular}{llllllcllll}
\hline Scales & $\begin{array}{l}\text { Programs } \\
\text { of study }\end{array}$ & $\mathrm{N}$ & $\mathrm{M}$ & $\mathrm{SD}$ & $\begin{array}{c}\text { Mean } \\
\text { Square }\end{array}$ & $\begin{array}{c}\mathrm{F} \\
(3, \\
372)\end{array}$ & $p$ & $\eta^{2}$ & Tukey \\
\hline LS & Science & 98 & 3.43 & .94 & 3.492 & 3.763 & $.011^{*}$ & .009 & \\
& Math & 76 & 3.49 & 1.06 & & & & & \\
& English & 75 & 3.58 & .93 & & & & & \\
PV & Science & 98 & 4.36 & .39 & .614 & 3.902 & $.009 *$ & .010 & $1>2$ \\
& Math & 76 & 4.20 & .41 & & & & & \\
& English & 75 & 4.15 & .42 & & & & & \\
\hline
\end{tabular}

Note: ${ }^{*} p<.05, \mathrm{PV}$ is Perceived value, LS is Leadership support

Similarly, one-way between-subjects ANOVA compared the teachers' mean scores based on the school location (see Table 5). Obviously, the urban school teachers use ICT more frequently than those teachers in semi-urban schools. In addition, urban school teachers receive more training and leadership support than teachers in semi-urban schools. 
Table 5. One-way ANOVA Results for Differences Based on Location of Study

\begin{tabular}{clcccccccc}
\hline Scales & $\begin{array}{l}\text { Location of } \\
\text { study }\end{array}$ & $\mathrm{N}$ & $\mathrm{M}$ & $\mathrm{SD}$ & $\begin{array}{c}\text { Mean } \\
\text { Square }\end{array}$ & $\begin{array}{c}\mathrm{F} \\
(2,372)\end{array}$ & $p$ & $\eta^{2}$ & Tukey \\
\hline ICT-U & Urban & 134 & 2.95 & 1.32 & 23.723 & 14.892 & $.000^{*}$ & .040 & $1>2 ;$ \\
& Semi-urban & 114 & 2.08 & 1.14 & & & & & $3>2$ \\
& Rural & 125 & 2.66 & 1.30 & & & & & \\
TR & Urban & 133 & 2.86 & 1.32 & 7.826 & 4.105 & $.017^{*}$ & .011 & $1>2$ \\
& Semi-urban & 114 & 2.38 & 1.43 & & & & & \\
& Rural & 126 & 2.76 & 1.40 & & & & & \\
LS & Urban & 135 & 3.69 & .82 & 9.898 & 11.076 & $.000^{*}$. & .030 & $1>2>3 ;$ \\
& Semi-urban & 115 & 3.17 & .99 & & & & & $3>2$ \\
& Rural & 126 & 3.26 & 1.02 & & & & & \\
\hline Note: ${ }^{*} \mathrm{p}<.05$, ICT-U is ICT usage, TR is Training, LS is Leadership support & & &
\end{tabular}

\section{Research Question 4: Relative Contribution of Factors to Teachers' Pedagogical Use of ICT}

To perform the multiple regression analysis, correlation among variables was initially calculated to check the assumption of multicollinearity. Based on Cohen's model (1988) which suggested that a coefficient between .30 and .49 indicates moderate correlation, all of the variables were moderately correlated with each other (see Table 6). Leadership support (Pearson Correlation Value $(r)=.55, p<.01)$ had the highest correlation with ICT use, followed by training $(r=.51, p$ $<.01)$. Self-efficacy was strongly correlated with competence $(r=.60, p<.01)$. In addition, perceived value $(r=.18, p<.01)$ and expectancy of success $(r=.21, p<.01)$ weakly correlated ICT usage respectively. However, since they weakly correlated with other independent variables, they posed no much concerns in terms of multicollinearity.

In the multiple regression analysis, the predictor variables were competence, access to computers, self-efficacy and leadership support. The dependent variable was ICT usage. The results found that competence $(\beta=.29)$, training $(\beta=.22)$, leadership support $(\beta=.38)$ and expectancy of success $(\beta=.11$ ) each made independent contributions to the equation predicting ICT usage. Leadership support was the most significant predictor, followed by competence. All the variables collectively accounted for $48.0 \%(R 2=0.48, F(7,367)=46.813, p<.05)$ of the variation in ICT.

Table 6. Correlations among the Variables.

\begin{tabular}{lcccccccc}
\hline Variable & $\mathrm{ICT}-\mathrm{U}$ & $\mathrm{COMP}$ & $\mathrm{AC}$ & $\mathrm{TR}$ & $\mathrm{LS}$ & $\mathrm{SE}$ & $\mathrm{PV}$ & $\mathrm{EOS}$ \\
\hline $\mathrm{ICT}-\mathrm{U}$ & - & & & & & & & \\
COMP & $.46^{* *}$ & - & & & & & & \\
AC & $.35^{* *}$ & $.56^{* *}$ & - & & & & \\
TR & $.51^{* *}$ & $.42^{* *}$ & $.36^{* *}$ & - & & & & \\
LS &. $.55^{* *}$ & $.23^{* *}$ & $.24^{* *}$ & $.42^{* *}$ & - & & & \\
SE & $.31^{* *}$ & $.60^{* *}$ & $.41^{* *}$ & $.25^{* *}$ & $.26^{* *}$ & - & & \\
PV & $.18^{* *}$ & $.18^{* *}$ & $.13^{* *}$ & .08 & .10 & $.37^{* *}$ & - & \\
EOS & $.21^{* *}$ & $.12^{*}$ & $.15^{* *}$ & .04 & $.11^{*}$ & $.21^{* *}$ & $.45^{* *}$ & - \\
\hline
\end{tabular}

Note: ${ }^{* *}$. Correlation was significant at .01 level (2-tailed); *. Correlation was significant at .05 level(2tailed). COMP is competence, AC is access, EOS is expectancy of success. 


\section{Discussion}

The study found that teachers are not often applying ICT in activities in connection with students' teaching. However, the highest frequencies of ICT use by teachers correspond to the most basic and traditional activities such as search for information and browse the relevant web site. This finding is line with earlier studies (Brun \& Hinostroza, 2014; Wikan \& Molster, 2011) and specifically with the assertion that ICT is used to support traditional teaching activities (Brun \& Hinostroza, 2014) and not to reform them (Karasavvidis, 2009). Therefore, it is clear from the results of this study that the anticipations of ICT integration into teaching and learning in schools in Ghana have not been accomplished yet because the use of ICT is still confined to basic and traditional activities.

The teachers' perceived value of ICT was found to be high. However, perceived value was found to be weakly correlated with ICT usage as reported in previous study (Chen, 2010). Though the teachers have recognized the importance of ICT in teaching, they do not apply ICT in schools. Teachers' perceived capability to integrate ICT into teaching successfully and give the preferred outcome is a determining factor. In the current study, not only teachers' expectancies of success of ICT integration were found to be high, but also weakly related to ICT usage. This suggests that teachers' do not possess the skills to successfully integrate ICT within their own educational environment. Therefore, it is necessary, but not sufficient to disclose to teachers how their colleagues have successfully implemented ICT in their teaching and to establish communities of practice to mutually support the teachers. Teachers' are more likely to integrate ICT into teaching if the perceived value of ICT and the expectancy of success are high (Wozney et al., 2006).

Also, gender differences were found to exist with regards to ICT usage. Female teachers were found to use ICT more than male teachers. This study is consistent with these studies (Majuto \& Gibert, 2015; Mustafa, 2014,) but contradicts other studies as well (Aslan \& Zhu, 2017; Fomsi $\&$ Orduah, 2017). This situation probably stems from the fact that female teachers receive more leadership support than male teachers as revealed in this study. In addition, gender differences were found to exist in terms of self-efficacy. This study agrees with these studies (Bao et al., 2013) but disagrees with other studies (Tarhini et al., 2014). The result of this study also revealed that science teachers perceived the use of ICT more useful than English teachers. This situation might arise from the fact that science teachers are more confident in applying ICT than the English teachers. The finding of this study is inconsistent with Tezci (2011) who found that Arts teachers have more self-confidence in ICT usage than science teachers. In another development, urban school teachers use ICT more frequently than teachers in semi-urban schools. This explains the fact that urban schools might be more resourced in terms of ICT infrastructure than semi-urban schools. This study is in agreement with other studies (Haji, Moluayonge \& Park, 2017; Pei-Yu, 2013). In addition, urban school teachers receive more training and leadership support than those teachers in semi-urban schools. The finding of this study is consistent with Yuan (2006) who reported that socioeconomic and regional locations of teachers may affect their use of ICT because of difference in availability, support and literacy.

This study found that leadership support strongly related to teachers' integration of ICT. This finding provides sufficient evidence that effective integration of ICT into teaching needs a school leadership support that provides its teachers with the requisite skills to successfully use ICT in their classroom teachings. Teachers who believe that they can have school leadership support to implement ICT successfully are more likely to use computers in their classrooms. This finding confirms Tezci's (2011) finding that school support influences pre-service and in-service 
teachers' ICT integration into teaching. Additionally, this study found that teachers' training influence their use of ICT in school. This implies that a wider range of leadership support in terms of provision of training in technology is needed for teachers to be able to integrate ICT into their teaching. This result of this study is in line with findings by other researchers (Boulton, 2017; Japhet \& Usman, 2018; Shin, 2015). Lastly, this study revealed that competence strongly correlated with self-efficacy. This suggests that increase in teachers' competence levels leads to higher self-confidence levels regarding ICT integration, which in turn would lead to effective integration of ICT into teaching. This finding is consistent with other studies as well (Chun-Mei, Chien-Hua, His-Chi, \& Tsu-Chuan, 2018; Japhet \& Usman, 2018).

\section{Conclusion}

Teachers are agents of change in schools. They are drivers who play important roles in implementation of ICT in education. If teachers' ICT integration is low, it affects it usage in classroom. The effect of ICT on students' learning will completely depend on the teachers. They decide on how best to influence knowledge. The integration of ICT will bring new, stimulating and fulfilling learning experiences to both educators and learners. Therefore, training teachers to possess the requisite knowledge and skills to effectively support their students' ICT usage in classrooms is necessary. In other words, training and competence are determinants of successful ICT integration in schools and classrooms. Teachers' positive perception of value and expectancies of success of ICT is an indication of their willingness to integrate ICT into their teaching. In other words, teachers who believe that technology can be usefulness tend to successfully use it in teaching. The debate on gender gap in the use of ICT in teaching still persists. The current study has contributed to the current debate by revealing that many female teachers use ICT. This implies that if females are given more opportunities to use ICT in their teaching, the gender gap in terms of ICT usage would gradually reduce. Finally, the current study was able to give evidence to support the claim that providing teachers with leadership support will lead them to integrate ICT into classroom activities to promote student learning. Thus, successful integration of ICT needs a school support that gives its teachers the requisite training in instructional use of technology to effectively integrate ICT into classroom activities.

\section{Limitations of the Study and Recommendations for Future Research}

The use of self-reported measures of leadership support, and pedagogical use of ICT may affect the results of the analysis. The use of survey method of data collection may affect the results. Interview method could also be adopted to triangulate teachers' data. A number of incomplete questionnaires were dropped from the data set. Enough time should be given to teachers to complete questionnaires in future studies. Finally, the survey instrument limits this study because of its lack of open ended questions that would increase the qualitative understanding of the research. More open-ended questions should be included in the questionnaire in future studies.

This study was limited to teachers in secondary schools. Future research can be extended to teachers in Colleges of Education, and tertiary institutions. The study investigated the factors affecting teachers' use of ICT in secondary schools. Teachers selected for this study were from all subject disciplines (Science, Mathematics, English etc.). Future studies may consider changing population, sampling procedure or data collection used in this study. For instance, future researchers may investigate the factors that influence teachers' use of ICT by selecting teachers 
from a specific subject discipline (such as Mathematics or Science). The current study used crosssectional approach to collect data on teachers' population, future research need to consider longitudinal design to examine the role of ICT over time.

\section{References}

Albirini, A. (2004). An exploration of the factors associated with the attitudes of high school EFL teachers in Syria toward Information and Communication Technology (Unpublished doctoral dissertation). Ohio State University, United States.

Appianing, J. \& van Eck, R.N. (2015). Gender differences in college students' perceptions of technology-related jobs in computer science. International Journal of Gender, Science and Technology, 7(1), 28-56.

Aslan, A., \& Zhu, C. (2017). Starting Teachers' Integration of ICT into Their Teaching Practices in the Lower Secondary Schools in Turkey. Educational Sciences: Theory \& Practice, 18(1), 23-45.

Aydin, M. K., Gurol, M., \& Vanderlinde, R. (2016). Evaluating ICT integration in Turkish K-12 schools through teachers' views. Eurasia Journal of Mathematics, Science \& Technology Education, 12(4), 747-766.

Aydin, S. (2013). Teachers' perceptions about the use of computers in EFL teaching and learning: the case of Turkey. Computer Assisted Language Learning, 26(3), 214- 233

Boulton, H. (2017). Exploring the effectiveness of new technologies: Improving literacy and engaging learners at risk of social exclusion in the UK. Teaching and Teacher Education, $63,73-81$.

Brun, M. \& Hinostroza, J. E. (2014). Learning to become a teacher in the 21st century: ICT integration in initial teacher training education in Chile. Educational Technology \& Society, 17(3), 222-238.

Cakir, R. \& Yildirim, S. (2013). ICT teachers' professional growth viewed in terms of perceptions about teaching and competencies. Journal of Information Technology Education: Innovations in Practice, 12, 221-237.

Caplan, R. D., Naidu, R. K., \& Tripathi, R. C. (1984). Coping and defense: Constellations vs components. Journal of Health and Social Behavior, 25(3), 303-320.

Chen, R.J. (2010). Investigating models for preservice teachers' use of technology to support student-centered learning. Computers \& Education, 55(1), 32-42.

Chun-Mei, C., Chien-Hua, S., Hsi-Chi, H., \& Tsu-Chuan, S. (2018). Factors influencing teachers' innovative teaching behaviour with information and communication technology (ICT): the mediator role of organisational innovation climate. Educational Psychology, 39(1), 65-85.

Cohen, J. W. (1988). Statistical power analysis for the behavioral sciences (2nd ed.). Hillsdale, NJ: Lawrence Erlbaum Associates.

Drent, M. \& Meelissen, M. (2008). Which factors obstruct or stimulate teacher educators to use ICT innovatively? Computers \& Education, 51, 187-199.

European Commission. (2013). Survey of schools: ICT in education. Brussels: European Commission. doi:10.2759/94499 
Ertmer, P. A. (2005). Teacher pedagogical beliefs: The final frontier in our quest for technology integration? Educational Technology Research and Development, 53(4), 25-39.

Feather, N. T. (1982). Expectations and actions: Expectancy-value models in psychology. Hillsdale, NJ: Erlbaum.

Fomsi, E.F. \& Orduah, S.E. (2017). Gender differences in the use of ICT among teachers in model primary schools in rivers state, Nigeria. British Journal of Education, 5(4), 88-94.

Grabe, M. \& Grabe, C., (2008). Integrating technology for meaningful learning (5th ed.). New York: Houghton Mifflin.

Gulbahar, Y. (2008a). Improving the technology integration skills of prospective teachers. Through practice: A case study. The Turkish Online Journal of Educational Technology. 7(4), 71-81.

Haji, S.A., Moluayonge, G.E., \& Park, I. (2017). Teachers' Use of Information and Communications Technology in Education: Cameroon Secondary Schools Perspectives. The Turkish Online Journal of Educational Technology, 16(3), 147-153.

Hassan, M., Rosnain, I. M., Ahmad, F. M. A., \& Su, L. W. (2016). Teachers' acceptance of ICT and its integration in the classroom. Quality Assurance in Education, 24(1), 26-40.

Haugsbakk, G. (2010). Digital skole pa sviktende grunn- om nye muligheter og dilemmaer. Oslo, Norway: Gyldendal akademiske.

Hew, K. F. \& Brush, T. (2007). Integrating technology into K-12 teaching and learning: current knowledge gaps and recommendations for future research. Educational Technology Research and Development, 55(3), 223-253.

Ilomaki, L., Kantosalo, A., \& Lakkala, M. (2011). What is digital competence? In linked portal. Brussels: European Schoolnet.

Japhet, E. L. \& Usman A. T. (2018). Factors that influence teachers' adoption and integration of ICT in teaching/learning process. Educational Media International, 55(1), 79-105.

Kamau, L.M., Kimani, P., \& Muthoni, P. (2016). Factors that influence teachers' perceptions of Information and communication technology (ICT) in mathematics teaching in Kenyan secondary schools. International Journal of Education and Practice, 4(4), 154-166.

Kaarakainen, M. T., Kivinen, O. \& Vainio, T. (2017) Performance-based testing for ICT skills assessing: A case study of students and teachers ICT skills in Finnish schools. Universal Access in the Information Society. doi: 10.1007/s10209-017-0553-9

Karasavvidis, I. (2009). Activity theory as a conceptual framework for understanding teacher approaches to information and communication technologies. Computers \& Education, 53(2), 436-444.

Khawaji, S.A.N. (2016). English Teacher's Perception and Practices towards Technology Implementation. International Journal of Language and Literature, 4(2), 123-133.

Kline, R. R. (2005). Principles and practice of structural equation modeling. New York: Guilford.

Kubiatko, M. \& Halakova, Z. (2009). Slovak High School students' attitudes to ICT using in biology lesson. Computers in Human Behavior, 25(3), 743-748.

Kwon, H., \& Chang, M. (2009). Technology teachers' beliefs about biotechnology and its instruction in South Korea. The Journal of Technology studies, 67-75. 
Lawless, K. \& Pellegrino, J. (2007). Professional development in integrating technology into teaching and learning: Knowns, unknowns and ways to pursue better questions and answers. Review of Educational Research, 77(4), 575-614.

Levin, T. \& Wadmany, R. (2008). Teachers' views on factors affecting effective integration of information technology in classroom: Developmental scenery. Journal of Technology and Teacher Education, 16(2), 233-236

Liaw, S., Huang, H., \& Chen, G. (2007). Surveying instructor and learner attitudes toward Elearning. Computers \& Education, 49(4), 1066-1080.

Majuto, M. \& Gilbert, M.G. (2015). The use of ICT between male and female teachers in Secondary Schools in Tanzania, a Case of Dodoma Municipality. International Journal of Education and Research, 3(12), 417-428.

Ministry of Education (2003). Information and communication technology for accelerated development. Accra, Ghana.

Ministry of Education. (2008). ICT Education policy. Accra, Ghana.

Mulhim, E. (2013, December). The current use of ICT by novice female teachers in Saudi primary schools and their perceived training needs. 30th ASCILITE Conference. Macquerie University, Sydney.

Mustafa, M.N. (2014). The effects of gender differences in ict application: Bridging the gap of knowledge and skills among teachers. Australian Journal of Basic and Applied Sciences, 8(10), 81-86.

Ola, J. L., Anders, D. O., \& Göran, F. (2017). Same but different? An examination of Swedish upper secondary school teachers' and students' views and use of ICT in education. International Journal of Information and Learning Technology, 34(2), 122-132.

Papanastasiou, E.C. \& Angeli, C. (2008). Evaluating the use of ICT application in education: Psychometric properties of the survey of factors affecting teachers teaching with technology (SFA-T3). Educational Technology \& Society, 11(1), 69-86.

Pei-Yu, W. (2013). Examining the Digital Divide between rural and urban schools: Technology availability, teachers' integration level and students' perception. Journal of Curriculum and Teaching, 2(2), 127-139.

Pelgrum, W. \& Anderson, R.E. (1999). ICT and the emerging paradigm for lifelong learning. A Worldwide educational assessment of infrastructure, Goals and practices. Amsterdam: International Association for the Evaluation of Educational Achievement.

Pelgrum, W.J. (2001). Obstacles to the integration of ICT in education: Results from a Worldwide Educational Assessment. Computers \& Education 37, 163-178.

Player-Koro, C. (2012). Factors influencing teachers' use of ICT in education. Education Inquiry, 3(1), 93-108.

Ritzhaupt, A. D., Liu, F., Dawson, K. \& Barron, A. E. (2013) Differences in student information and communication technology literacy based on socio-economic status, ethnicity, and gender. Journal of Research on Technology in Education, 45 (4), 291-307.

Sang, G., Valcke, M., Braak, V. \& Tondeur, J. (2010). Student teachers' thinking processes and ICT integration: predictors of prospective teaching behaviors with educational technology. Computers \& Education, 54(1), 103-112. 
Schiller, J. (2003). Working with ICT perceptions of Australian Principals. Journal of Educational Administration, 41(2), 171-185.

Shin, W. S. (2015). Teachers' use of technology and its influencing factors in Korean elementary schools. Technology, Pedagogy and Education, 24(4), 461-476.

Sipila, K. (2014). Educational use of information and communications technology: teachers' perspective. Technology, Pedagogy and Education, 23(2), 225-241.

Tarhini, A., Hone, K., \& Liu, X. (2014). Measuring the moderating effect of gender and age on elearning acceptance in England: a structural equation modeling approach for an extended technology acceptance model. Journal of Educational Computing Research, 51(2), 163-184.

Teo, T. (2008). Pre-service teachers' attitudes towards computer use: A Singapore survey. Australasian Journal of Educational Technology 24(4), 413-424

Tezci, E. (2011). Factors that influence pre-service teachers' ICT usage in education. European Journal of Teacher Education, 34(4), 483-499.

Tondeur, J., Valcke, M., \& van Braak, J. (2008b). A multidimensional approach to determinants of computer use in primary education: Teacher and school characteristics. Journal of Computer Assisted Learning, 24, 494-506.

Tubin, D. (2007). When ICT meets schools: Differentiation, complexity and adaptability. Journal of Educational Administration, 45(1), 8-32.

Twining, P. \& Henry, F. (2014). Enhancing ICT teaching in English schools: Vital Lessons. World Journal of Education, 4(2), 12-36.

Uluyol, C. \& Sahin, S (2016). Elementary school teachers' ICT use in the classroom and their motivators for using ICT. British Journal of Educational Technology, 47(1), 65-75.

Vitanova, V., Pachemska, T.A., \& Pachemska, S. (2014). Factors affecting the frequency of ICT usage in primary schools teaching. The Eurasia Proceedings of Educational \& Social Sciences, 1, 461-468.

Voogt, J. \& Roblin, N., P. (2012). A comparative analysis of international frameworks for $21^{\text {st }}$ century competences: Implications for national curriculum policies. Journal of Curriculum Studies, 44(3), 299-321.

Wastiau, P. \& Pagano, P. (2013). The 'teacher effect' on the use of ICT in the classroom. European Schoolnet, 1, 1-4.

Wigfield, A. (1994). Expectancy-value theory of achievement motivation: A developmental perspective. Educational Psychology Review, 6(1), 49-78.

Wigfield, A. \& Eccles, J.S. (2000). Expectancy-value theory of achievement motivation. Contemporary Educational Psychology, 25, 116-119.

Wikan, G. \& Molster, T. (2011). Norwegian secondary school teachers and ICT. European Journal of Teacher Education, 34(2), 209-218.

Wong, K, T., Teo, T., \& Russo, S. (2012). Influence of gender and computer teaching efficacy on computer acceptance among Malyasian student teachers: An extended technology acceptance model. Australiasian Journal of Educational Technology, 28(7), 1190-1207. 
Wozney, L., Venkatesh, V., \& Abrami, P. (2006). Implementing computer technologies: Teachers' perceptions and practices. Journal of Technology and Teacher Education, 14(1), 173-207.

Yuan, M. X. (2006). The theory of constructivism and the reform of teacher education. Journal of Yangzhou Teacher College, 24(2), 41-49.

Yuen, A. H. K., \& Ma, W. W. K. (2008). Exploring teacher acceptance of E-learning technology. Asia-Pacific Journal of Teacher Education, 36(3), 229-243.

Correspondence: Charles Buabeng-Andoh, Senior Lecturer, Department of ICT Education, University of Education, Winneba, Central Region, Ghana 